\title{
Kombinasi relaksasi otot progresif dan terapi musik tradisional Bali efektif menurunkan stres kerja petani
}

\section{Progressive muscle relaxation and Balinese music is effective in reducing the stress of farmers}

\author{
Cristin Wiyani ${ }^{1}$, Ririn Wahyu Widayati ${ }^{2}$, Ni Kadek Rai Nining Sonia Dewi ${ }^{3}$, \\ Siti Fadlilah ${ }^{*}$ \\ 1,2,3,4 Universitas Respati Yogyakarta, Sleman, Yogyakarta, Indonesia \\ ${ }^{1}$ christin.wiyani@gmail.com; ${ }^{2}$ ririnwahyu@ respati.ac.id; ${ }^{3}$ raininingsonia@gmail.com, \\ ${ }^{4}$ sitifadlilah@ respati.ac.id* \\ *corresponding author \\ Tanggal Submisi: 20 Oktober 2021, Tanggal Penerimaan: 8 November 2021
}

\begin{abstract}
Abstrak
Penelitian ini bertujuan mengetahui pengaruh kombinasi relaksasi otot progresif dan terapi musik tradisional terhadap stres kerja petani di Bali. Penelitian menggunakan desain quasy experiment pre-posttest nonequivalent control group. Responden terdiri 2 kelompok masing-masing 18 orang, dengan consecutive sampling. Instrumen berupa standar operasional prosedur, lembar observasi, dan kuesioner International Stress Management Association (ISMA). Uji statistik menggunakan Wilcoxon. Terdapat penurunan median skor stres kelompok kontrol dan intervensi yaitu 0,50 dan 1,50. Hasil p-value pre-posttest kelompok kontrol dan itervensi yaitu 0,015 dan 0,000. Uji beda posttest antar kelompok didapatkan p-value 0,630. Ada pengaruh kombinasi relaksasi otot progresif dan terapi musik tradisional Bali terhadap stres kerja petani di Tabanan Bali.
\end{abstract}

Kata kunci: relaksasi otot progresif; terapi musik; stres kerja

\begin{abstract}
This study aims to determine the effect of the combination of progressive muscle relaxation and traditional music therapy on the work stress of farmers in Bali. The study used a quasi-experimental pre-post test nonequivalent control group design. Respondents consisted of 2 groups of 18 people each, taken by consecutive sampling. Standard operating procedures, observation sheets, and the International Stress Management Association (ISMA) questionnaire are used. Statistical test using paired t-test and independent $t$-test. There was a decrease in the median stress scores in the control and intervention groups, 0.39 and 0.95. The pre-posttest bivariate test for the control and intervention groups were $p$ values of 0.015 and 0.000 . The posttest difference test between groups obtained a $p$-value of 0.630. There is an effect of a combination of progressive muscle relaxation and traditional Balinese music therapy on the work stress of farmers in Tabanan Bali.
\end{abstract}

Keywords: progressive muscle relaxation; music therapy; stress 


\section{PENDAHULUAN}

Petani merupakan seorang penggerak utama pada bidang bisnis pertanian meliputi proses produkis bahan makanan dari hewan dan tumbuhan. Petani juga melakukan usaha pembeharuan dan pengembangan produk dengan tetap memperhatikan faktor ekonomi (Wurarah et al., 2020). Banyaknya kegiatan yang harus dikerjakan dan tuntutan waktu yang singkat membuat beban kerja petani bertambah. Petani dituntut mempunyai kemampuan melaksanakan pekerjaan dengan teliti. Masalah yang dapat terjadi pada petani-petani antara lain jam kerja yang tidak tebatas dengan minimal 7-8 jam/hari dan adanya resiko penyakit akibat kerja. Petani juga banyak menggunakan tenaga fisik. Hal-hal tersebut dapat menjadikan beban kerja bagi petani. Beban kerja yang banyak menyebabkan tingginya stres kerja petani (Rizqiansyah et al., 2017).

Prevalensi kasus stres, depresi, atau kecemasan terkait pekerjaan pada 2020/2021 adalah tingkat prevalensi 2.480 per 100.000 pekerja (Executive, 2019). Data stress kerja di dunia mencapai 65\%, sedangkan stres kerja di Indonesia sebanyak 73,25\%. Kejadian gangguan mental emosional berupa stres kerja dari 150 juta penduduk usia dewasa sebanyak 11,6-17,4\%. Stres kerja petani di Indonesia mencapai $57,7 \%$, sedangkan angka kejadian stres kerja petani di Tabanan Bali sebesar 66,7\% (Statistik, 2012).

Stres kerja merupakan gangguan yang terjadi pada fisik dan emosional yang disebabkan oleh ketidakseimbangan kebutuhan, kemampuan, dan sumber daya yang dimiliki oleh pekerja. Kesehatan dan keselamatan pekerja dapat dipengaruhi oleh stres kerja, bahkan stres kerja yang tinggi dapat menyebabkan kecelakaan. Jika tidak segera ditangani akan berdampak pada fisik maupun psikologis seperti sakit kepala, kram otot, pusing, mudah marah serta rasa jengkel dan jenuh. Selain dapat tersebut stres kerja juga berdampak pada kejenuhan bekerja, penurunan motivasi kerja. Kematian akibat kelelahan akibat kerja bahkan kejadian bunuh diri dapat menjadi dampak paling buruk dari stres kerja (Siagian, 2012) (Rizqiansyah et al., 2017) (Jundillah et al., 2017) (Samura \& Sitompul, 2020).

Adanya dampak buruk dari stres kerja memerlukan adanya manajemen stres, salah satunya menggunakan metode nonfarmakologis. Metode non farmakologis untuk mengurangi stres menggunakan terapi alternatif sebagai pengganti praktik pengobatan kedokteran. Terapi alternatif relaksasi otot progresif (ROP) (Paramita, 2019) dan terapi musik dapat digunakan untuk menurunkan (Supriadi et al., 2015). Relaksasi otot progresif adalah metode yang dapat dimanfaatkan untuk mengurangi stres. Terapi ini melibatkan penggabungan antara pikiran dan tubuh (mind body therapy). Keunggulan dari terapi ROP dapat dilakakukan dengan mudah, murah, dan mandiri (Ilmi et al., 2017). Hasil penelitian (Asiah \& Warsito, 2018), membuktikan terapi ROP efektif menurunkan stres. Selain terapi ROP, manajemen stres bisa juga dilakukan dengan terapi musik.

Musik dapat mempengaruhi seseorang dari berbagai aspek, yaitu emosional, spiritual, bahkan fisik. Getaran musik mampu mempengaruhi frekuensi tubuh sehingga dapat membantu proses penyembuhan bersama dengan terapi medis yang diberikan (Windyastuti et al., 2016). Pemanfaatan terapi musik sudah digunakan di dunia medis dan keperawatan, bukan hanya sebatas di bidang

Cristin Wiyani, et. al (Kombinasi relaksasi otot progresif dan terapi musik tradisional....) 
ilmu psikologi. Manfaat terapi musik antara lain untuk mengelola stres, manajemen nyeri, dan merangsang proses tumbuh kembang (Supriadi et al., 2015). Jenis musik yang dapat digunakan untuk terapi bermacam-macam, pertimbangan utama adalah dikenal dan disukai oleh klien. Indonesia mempunyai jenis musik yang beragam sesuai dengan daerah asal, dikenal dengan music tradisional. Salah satu music tradisional berasal dari Bali. Musik tradisional Bali mempunyai karakteristik alunan yang lembut, memenuhi syarat untuk terapi musik. Musik tradisional Bali bersifat menenangkan dan dapat menurunkan kecemasan (Somoyani et al., 2013).

Hasil studi pendahuluan yang telah dilakukan pada 13 orang petani di Banjar Bongan Jawa Tabanan Bali diperoleh bahwa semua mengungkapkan adanya gejala stres kibat kerja. Gejala berupa susah tidur, tertekan, khawatir, susah konsentrasi, mudah lelah, sampai dengan lebih mudah tersinggung. Petani mengatakan mempunyai tuntutan pekerjaan yang sangat banyak. Hal yang dilakukan petani untuk mengurangi stres yaitu dengan cara beristirahat, mendengarkan musik, mengobrol bersama teman-teman dan nongkrong. Dari hasil wawancara petani tidak mengetahui manfaat kombinasi relaksasi otot progresif dan terapi musik tradisional Bali untuk mengurangi stres dan belum pernah mendapatkan terapi ini sebelumnya.

Penelitian Maryana et al. (2014) (2014) dan Rina et al. (2020), menunjukkan terapi musik efektif menurunkan stres kerja perawat. Penelitian sebelumnya hanya menggunakan terapi musik untuk intervensi dan perawat sebagai responden, sedangkan penelitian ini menggunakan kombinasi ROP dan terapi musik dengan petani sebagai responden. Penelitian Puspita Sari et al. (2019) dan Asiah \& Warsito (2018), membuktikan bahwa ROP efektif menurunkan stress kerja. Penelitian tersebut hanya menggunakan ROP sebagai intervensi dan responden pekerja kantoran, sedangkan penelitian ini menggunakan kombinasi ROP dan terapi musik dengan petani sebagai responden. Penelitianpenelitian tentang manfaat terapi ROP dan terapi musik telah banyak dilakukan, tetapi peneliiti belum menemukan penelitian tentang kombinasi dua intervensi tersebut. Peneliti juga menggunakan musik tradisional Bali yang belum banyak digunakan sebagai media intervensi. Berdasarkan latar belakang tersebut, tujuan penelitian ini yaitu untuk mengetahuai pengaruh kombinasi relaksasi otot progresif dan terapi musik tradisional Bali terhadap stres kerja petani di Banjar Bongan Jawa Tabanan Bali.

\section{METODE}

Jenis penelitian quasy experiment dengan desain pretest-posttest nonequivalent control group. Penelitian dilakukan di Banjar Bongan Jawa Tabanan Bali pada tanggal 12-14 Agustus 2021. Populasi pada penelitian ini adalah petani di Banjar Bongan Jawa yang berjumlah 150 orang. Sampel ditentukan berdasarkan kriteria inklusi yaitu petani yang bersedia menjadi responden, menyukai musik tradisional Bali, memiliki lahan sendiri, dan mengikuti seluruh proses intervensi. Kriteria eksklusi meliputi mengalami gangguan muskuloskeletal, mengalami gangguan pendengaran, mendapatkan terapi lain untuk mengurangi stres, dan tekanan darah $<90 \mathrm{mmHg}$. Sampel dibagi menjadi kelompok kontrol dan kelompok intervensi. Sampel diambil 
menggunakan teknik consecutive sampling dan dihitung berdasarkan rumus berikut,

$$
s=\frac{\lambda^{2} \cdot \mathrm{N} \cdot \mathrm{P} \cdot \mathrm{Q}}{d^{2}(N-1)+\lambda^{2} \cdot P \cdot Q}
$$

Hasil perhitungan sampel dan penambahan untuk antisipasi drop out sebanyak 20\% didapatkan sebanyak 18 responden tiap kelompok. Kombinasi relaksasi otot progresif dan terapi musik tradisional Bali menjadi variabel bebas dan stres kerja menjadi variabel terikat. Stres kerja merupakan pernyataan petani di Banjar Bongan Jawa mengenai respon psikologis, fisiologis, dan perilaku yang diakibatkan karena adanya tekanan atau sumber stres yang didapat selama menjalani pekerjaan. Stres kerja terdiri dari pretest dan posttest. Stres kerja pretest diukur 10 menit sebelum diberikan intervensi. Stres kerja posttest diukur 10 menit setelah intervensi di hari ketiga. Stres kerja diukur menggunkan kuesioner International Stress Management Association (ISMA). Kombinasi relaksasi otot progresif dan terapi musik adalah suatu tindakan yang diberikan kepada petani di Banjar Bongan Jawa berupa perpaduan relaksasi otot progresif dan terapi musik tradisional Bali yang diberikan bersama-sama. Intervensi dilakukan selama tiga hari berturut-turut dengan selama 20 menit tiap sesi. Uji normalitas data menggunakan Shapiro Wilk dengan hasil terdistribusi tidak normal sehingga uji yang digunakan adalah Wilcoxon. Penelitian dilakukan setelah mendapatkan kelayakan etik dari komisi etik UNRIYO dengan nomor 162.3/FIKES/PL/VIII/2021.

\section{HASIL DAN PEMBAHASAN}

Table 1. Karakteristik Responden

\begin{tabular}{|c|c|c|c|c|c|c|c|}
\hline \multicolumn{2}{|c|}{ Variabel } & \multicolumn{2}{|c|}{ Kelompok Kontrol } & \multicolumn{2}{|c|}{$\begin{array}{l}\text { Kelompok } \\
\text { Intervensi }\end{array}$} & \multicolumn{2}{|c|}{ Total } \\
\hline & & $\mathbf{n}$ & $\%$ & $\mathbf{N}$ & $\%$ & $\mathbf{N}$ & $\%$ \\
\hline \multirow[t]{2}{*}{ Jenis Kelamin } & Perempuan & 8 & 44,4 & 4 & 22,2 & 12 & 33,3 \\
\hline & Laki-laki & 10 & 55,6 & 14 & 77,8 & 24 & 66,7 \\
\hline \multirow[t]{3}{*}{ Usia } & Remaja & 1 & 5,6 & 4 & 22,2 & 5 & 13,9 \\
\hline & Dewasa & 11 & 61,1 & 10 & 55,6 & 21 & 58,3 \\
\hline & Lansia & 6 & 33,4 & 4 & 22,2 & 10 & 27,8 \\
\hline \multirow[t]{3}{*}{ Lama Bekerja } & $<5$ tahun & 0 & 0 & 2 & 11,1 & 2 & 5,6 \\
\hline & 5-10 tahun & 5 & 27,8 & 4 & 22,2 & 9 & 25,0 \\
\hline & $>5$ tahun & 13 & 72,2 & 12 & 66,7 & 25 & 69,4 \\
\hline
\end{tabular}

Tabel 1 diketahui sebagian besar responden adalah laki-laki (66,7\%) dengan sebaran 10 orang di kelompok kontrol dan 14 orang di kelompok intervensi. Usia dikelompokkan menjadi remaja (17-25 tahun), dewasa (26-35 tahun), dan lansia (46-65 tahun). Responden sebagian besar kategori dewasa $(58,3 \%)$, terdiri dari 11 orang di kelompok kontrol dan 10 orang di kelompok intervensi. Mayoritas responden telah bekerja sebagai petani selama $>5$ tahun, sebanyak 13 orang di kelompok kontrol dan 12 orang kelompok intervensi. 
Table 2. Perbedaan Stres Kerja antara Kelompok Kontrol dan Intervensi

\begin{tabular}{lccccc}
\hline Stres Kerja & $\boldsymbol{\Sigma}$ & Min-Mak & Median \pm SD & Selisih Median & p-value \\
\hline Kontrol & 18 & $8-15$ & $10,5 \pm 2,53$ & $-0,50$ & 0,015 \\
Pretest & 18 & $7-14$ & $10,0 \pm 1,87$ & & \\
Posttest & & & & & \\
Intervensi & 18 & $7-15$ & $12,0 \pm 2,44$ & $-1,50$ & 0,000 \\
Pretest & 178 & $6-13$ & $10,5 \pm 1,98$ & & \\
Posttest & & &
\end{tabular}

Tabel 2 menunjukkan adanya penurunan skor stres kerja di kelompok kontrol dan intervensi, yaitu 0,50 dan 1,50. Uji pre-posttest kelompok kontrol dan intervensi didapatkan $p$-value 0,015 dan 0,000. Hasil menunjukkan ada perbedaan skor stres pretest dan posttest pada kelompok kontrol. Hasil juga menunjukkan adanya pengaruh kombinasi terapi ROP dan terapi musik tradisional Bali terhadap stres kerja petani di Tabanan Bali.

Table 3. Perbedaan Stres Kerja antara Kelompok Kontrol dan Intervensi

\begin{tabular}{lcccc}
\hline \multicolumn{1}{c}{ Stres Kerja } & $\boldsymbol{\Sigma}$ & $\begin{array}{c}\text { Selisih } \\
\text { Median Pre- } \\
\text { posttest }\end{array}$ & Selisih Median & p-value \\
\hline Posttest kontrol & 18 & $-0,50$ & 1,00 & 0,630 \\
Posttest intervensi & 18 & $-1,50$ & \\
\hline
\end{tabular}

Tabel 3 menunjukkan uji posttest kelompok kontrol dan intervensi menunjukkan $p$-value 0,630. Hasil menunjukkan tidak ada perbedaan signifikan antara kelompok kontrol dan intervensi dalam penurunan skor stres kerja. Meskipun tidak terdapat hubungan, dilihat dari penurunan skor stres kerja saat pretest-posttest kelompok intervensi lebih banyak dibandingkan kelompok kontrol yaitu sebanyak 1,00 .

Hasil penelitian ini menunjukkan nilai stres kerja saat pretest kelompok kontrol dan intervensi termasuk dalam tingkat stres sedang. (Folkman, 2011), menjelaskan bahwa tingkat stres sedang mempunyai skor 5-13. Stres sedang dapat mnyebabkan masalah secara fisik, psikologis atau gabungan keduanya. Gejala fisik yang timbul meliputi gangguan terjadi hampir di seluruh sistem tubuh. Stres dapat meningkatkan adrenalin sehingga menyebabkan peningkatan tekanan darah, denyut nadi, dan gangguan kardiovaskuler lain. Stres juga dapat mengganggu sistem pencernaan seperti diare, sembelit, sakit perut, gusi berdarah, peningkatan asam lambung yang berakibat mual, muntah. Stres juga berakibat adanya gangguan pernapasan, rasa sakit kepala, kram otot, mudah lelah, hingga timbulnya jerawat. Dampak stres secara psikologis berupa gangguan mood yaitu cemas, bingung, sensitif, mudah marah, perasaan bosan, tegang, dan merasa tertekan. Dampak lainnya seperti gangguan konsentrasi, gangguan tidur, perubahan pola makan, penyempitan fokus, dan penurunan semangat bekerja (Chomaria, 2018) (Saam, Z., \& Wahyuni, 2014).

Stres apabila tidak dikelola dengan baik mengakibatkan stresor menjadi lebih besar dibandingkan daya tahan seseorang. Kondisi ini menyebabkan peningkatan hormon stres yang berdampak pada peningkatan level stress (Potter, P. A., \& Perry, 2005). Hasil penelitian menunjukkan adanya pengaruh kombinasi 
terapi kombinasi ROP dan terapi musik tradisional Bali terhadap stres kerja petani di Tabanan Bali. Sejalan penelitian sebelumnya dari (Asiah \& Warsito, 2018) menyebutkan bahwa ROP berguna untuk mengatasi stres dari sedang menjadi ringan. Penelitian oleh (Sari et al., 2019), juga menunjukkan adanya pengaruh terapi ROP terhadap tingkat stres kerja.

Cara kerja terapi ROP dengan melibatkan manajemen diri individu sehingga dapat mempengaruhi kerja sistem saraf simpatis dan parasimpatis. Relaksasi otot progresif dapat menurunkan konsumsi oksigen dalam tubuh, menurunkan tekanan darah, dan meningkatkan gelombang alfa pada otak (Resti, 2014) (Sundram et al., 2016) (Fadlilah et al., 2020). Selain itu, terapi musik mampu mengatasi stres dan tidak memiliki resiko maupun efek samping. Manfaat yang didapatkan setelah terapi music yaitu rasa tenang dan rileks. Oleh karena itu, terapi ini dapat meningkatkan proses pemulihan seseorang ditinjau dari aspek fisik, psikologis, dan spiritual (Djohan, 2010).

Intervensi yang diberikan kepada responden sama-sama dapat menimbulkan rasa tenang dan relaks. Efek tersebut akan menurunkan gejala yang timbul akibat stres sehingga mengurangi dampak negatif stres. Terapi kombinasi ROP dan terapi musik diharapkan dapat menjadi pilihan terapi bagi masyarakat untuk mengelola stress akibat kerja yang dirasakan. Sejalan dengan hal tersebut responden pada kelompok intervensi menunjukkan respon baik setelah diberikannya terapi, terbukti sebagian responden menyatakan secara lisan merasa lebih relaks dan nyaman, dapat tidur dengan nyenyak serta pikiran menjadi lebih lebih santai setelah diberikannya intervensi. Kegiatan yang dilakukan dengan perasaan tenang dan senang mampu merangsang pengeluaran hormone endorphin. Hormon ini mampu meningkatkan rasa tenang dan bahagia, sehingga merilekskan sistem muskuloskeletal (Mumpuni \& Wulandari, 2010).

Hasil penelitian juga menunjukkan ada perbedaan skor stres pretest dan posttest pada kelompok kontrol, yaitu penurunan skor stres kerja saat posttest. Penurunan skor stres tersebut dapat disebabkan karena responden memiliki manajemen diri yang berbeda-beda. Penelitian sebelumnya menyebutkan manajemen diri (self management) mempengaruhi respon saat menghadapi stres. Manajemen diri merupakan teknik yang digunakan diri seseorang dalam mnegelola kesehatan dan kehidupan tanpa bantuan orang lain yang profesional. Manajemen diri terdiri dari selfcare, cognitive, avoidance, connectedness, pleasurable activities, dan achievent. Kegiatan yang termasuk dalam selfcare seperti makan, minum, istirahat, olahraga, relaksasi, perawatan kesehatan, dan pengobatan. Perilaku cognitive meliputi berdoa dan berpikir. Avoidance meliputi pengalihan, menyibukkan diri, dan penggunaan obat-obatan. Connectedness melakukan kegiatan yang berhubungan dengan lainnya seperti memelihara hewan peliharaan, komunikasi dengan teman atau keluarga, bergaul dengan komunitas. Pleasurable activities melakukan kegiatan yang menyenangkan antara lain menonton TV dan menggunakan telepon genggam). Achievent dapat berupa membuat daftar prioritas dan melakukan pekerjaan rumah (Shepardson et al., 2017).

Reaksi seseorang saat menghadapi stres berbeda-beda. Banyak faktor yang mempengaruhi perbedaan tersebut, seperti usia, jenis kelamin, kondisi kesehatan, kepribadian, dan pengelolaan emosi. Besar dan jumlah stresor, mekanisme koping, dan pengalaman terhadap stress sebelumnya juga memppengaruhi respon 
stress seseorang. Penurunan skor stres keja di kelompok kontrol, dapat pula dikarenakan mekanisme koping yang dimiliki pada responden baik. Sejalan dengan penelitian sebelumnya didapatkan respon stres seseorang bergantung pada mekanisme koping yang dimiliki. Selain mekanisme koping yang baik, setiap individu juga memiliki manajemen diri untuk mengatasi stres yang diatasi (Priyoto, 2014) (Hidayat \& Uliyah, 2014). Saat dilakukan studi pendahuluan beberapa responden mengatakan kegiatan yang dilakukan saat mengalami stres adalah jalan-jalan, bercerita dengan keluarga atau teman, mendengarkan musik dan tidur.

Hasil penelitian ini menunjukkan tidak ada perbedaan antara kelompok kontrol dan intervensi. Hal ini terjadi karena ada banyak faktor yang dapat mempengaruhi pemberian terapi salah satunya yaitu lingkungan. Sejalan dengan penelitian sebelumnya menyebutkan ada 2 faktor yang berpengaruh pemberian terapi yaitu internal dan faktor eksternal. Faktor internal meliputi keadaan kesehatan, dan masalah pribadi, sedangkan faktor eksternal meliputi lingkungan terapi itu sendiri (Suwartika et al., 2014). Meskipun secara statistik menunjukkan tidak adanya perbedaan, tetapi penurunan stres kerja kelompok intervensi lebih besar dibandingkan dengan kelompok kontrol. Hal ini mendukung keefektifan terapi kombinasi ROP dan terapi musik tradisional Bali dalam menurunkan stres kerja petani.

\section{SIMPULAN}

Hasil penelitian menunjukkan terapi kombinasi relaksasi otot progresif dan terapi musik tradisional Bali dalam menurunkan stres kerja petani di Tabanan Bali. Penurunan nilai stres kerja responden kelompok intervensi lebih besar dibandingkan kelompok kontrol.

\section{DAFTAR PUSTAKA}

Asiah, A., \& Warsito, B. E. (2018). Pengaruh terapi relaksasi otot progresif terhadap stress. Jurnal Kesehatan, 9(2), 119-123. https://doi.org/10.38165/JK.V9I2.87

Chomaria, N. (2018). Bye-Bye Stress. PT Elex Media.

Djohan. (2010). Respons Emosi Musikal. Lubuk Agung.

Executive, H. and S. (2019). Work-related stress, anxiety or depression statistics in Great Britain. March. https://www.hse.gov.uk/statistics/causdis/stress.pdf

Fadlilah, S., Erwanto, R., Sucipto, A., Anita, D. C., \& Aminah, S. (2020). Soak feet with warm water and progressive muscle relaxation therapy on blood pressure in hypertension elderly. Pakistan Journal of Medical and Health Sciences, 14(3), 1444-1448.

Folkman, S. (2011). Stress Questionnaire. Wellness and Self-Care Library, O(1088103), 12. https://doi.org/10.1037/t06129-000

Hidayat, A. A., \& Uliyah, M. (2014). Pengantar Kebutuhan Dasar Manusia. Salemba Medika.

Ilmi, Z. M., Dewi, I., Rasni, H., Studi, P., Keperawatan, I., Jember, U., Kalimantan, J., Kampus, N., \& Boto Jember, T. (2017). Pengaruh Relaksasi Otot Progresif Terhadap Tingkat Stres Narapidana Wanita di Lapas Kelas IIA Jember (The Effect of Progressive Muscle Relaxation on Women 
Prisoners's Stress Levels at Prison Class IIA Jember). Pustaka Kesehatan, 5(3), 497-504. https://jurnal.unej.ac.id/index.php/JPK/article/view/6141

Jundillah, Z. N., Ahmad, L. O. A. I., \& Saktiawan, L. O. (2017). Analisis kejadian stres kerja pada perawat di Kabupaten Konawe Kepulauan tahun 2017. (Jurnal Ilmiah Mahasiswa Kesehatan Masyarakat), 2(6). https://doi.org/10.37887/JIMKESMAS.V2I6.2902

Maryana, Ariani, S., \& Suryani, E. (2014). Pengaruh Terapi Musik terhadap Penurunan Tingkat Stress Kerja Perawat di Unit Perawatan Kritis. Jurnal Keperawatan Notokusumo, 2(1), 18-24. https://jurnal.stikesnotokusumo.ac.id/index.php/jkn/article/view/24

Mumpuni, Y., \& Wulandari, A. (2010). Cara Jitu Mengatasi Stres. C. V Andi Offset.

NK Somoyani et al. (2013). Terapi musik klasik dan musik bali menurunkan intensitas nyeri persalinan kalai i fase aktif. Jurnal Skala Husada, 11(1), 1823.

Paramita, N. S. (2019). Pengaruh Kombinasi Relaksasi Otot Progresif Dan Aromaterapi Lemon Terhadap Skor Stres Pada Mahasiswa Keperawatan Unriyo.

Potter, P. A., \& Perry, A. G. (2005). Buku Ajar Fundalmental Keperawatan: Konsep, Proses, dan Praktik. ECG.

Priyoto. (2014). Konsep Manajemen Stres. Nuha Medika.

Puspita Sari, R., Pratiwi, A., Setia Sari Dosen Program, R. S., STIKes YATSI Dosen Program, K. S., \& STIKes YATSI, K. (2019). Pengaruh Teknik Relaksasi Otot Progresif Terhadap Tingkat Stres Kerja Pada Staff Stikes Yatsi. Jurnal Kesehatan, 8(2), 78-87. https://doi.org/10.37048/KESEHATAN.V8I2.143

Resti, I. B. (2014). Teknik relaksasi otot progresif untuk mengurangi stres pada penderita asma. Jurnal Ilmiah Psikologi Terapan, 2(1), 01-20. https://doi.org/10.22219/JIPT.V2I1.1766

Rina, E. I., Novitasari, D., \& Wirakhmi, I. N. (2020). Efektivitas terapi musik terhadap penurunan stres kerja perawat di Instalasi Rawat Jalan Rumah Sakit Umum Harapan Ibu Purbalingga pada masa pandemi. Viva Medika: Jurnal Kesehatan, Kebidanan Dan Keperawatan, 14(01), 110-119. https://doi.org/10.35960/VM.V14I01.561

Rizqiansyah, M. Z. A., Hanurawan, F., \& Setiyowati, N. (2017). Hubungan antara beban kerja fisik dan beban kerja mental berbasis ergonomi terhadap tingkat kejenuhan kerja pada karyawan PT Jasa Marga (Persero) Tbk Cabang Surabaya Gempol. Jurnal Sains Psikologi, 6(1), 37-42. https://doi.org/10.17977/UM023V6I12017P37-42

Saam, Z., \& Wahyuni, S. (2014). Psikologi Keperawatan. Rajawali Pers.

Samura, M. D., \& Sitompul, F. (2020). Analisis faktor-faktor yang mempengaruhi stres kerja pada karyawan. Jurnal Inovasi Kesehatan Masyarakat, 1(2), 5259. https://doi.org/10.36656/JIKM.V1I2.283

Shepardson, R. L., Tapio, J., \& Funderburk, J. S. (2017). Self-Management Strategies for Stress and Anxiety Used by Nontreatment Seeking Veteran Primary Care Patients. Military Medicine, 182(7), e1747-e1754. https://doi.org/10.7205/MILMED-D-16-00378

Siagian, S. (2012). Teori Motivasi dan Aplikasinya. Rineka Cipta. 
Statistik, B. P. (2012). Informasi Kependudukan Indonesia 2012. https://www.bps.go.id/publication/2012/09/24/b54178dc5e6a0581a3b436ee/ statistik-indonesia-2012.html

Sundram, B. M., Dahlui, M., \& Chinna, K. (2016). Effectiveness of progressive muscle relaxation therapy as a worksite health promotion program in the automobile assembly line. Industrial Health, 54(3), 204-214. https://doi.org/10.2486/INDHEALTH.2014-0091

Supriadi, D., Hutabarat, E., Monica, V., \& Jenderal Achmad Yani, Stik. (2015). Pengaruh terapi musik tradisional kecapi suling sunda terhadap tekanan darah pada lansia dengan hipertensi. Jurnal Skolastik Keperawatan, 1(2), 2935. https://doi.org/10.35974/jsk.v1i2.80

Suwartika, I., Nurdin, A., Ruhmadi, E., Politeknik, D., \& Kemenkes Tasikmalaya, K. (2014). Analisis Faktor Yang Berhubungan Dengan Tingkat Stress Akademik Mahasiswa Reguler Program Studi D III Keperawatan Cirebon Poltekkes Kemenkes Tasikmalaya. Jurnal Keperawatan Soedirman, 9(3), 173-189. https://doi.org/10.20884/1.JKS.2014.9.3.612

Windyastuti, E., S-, P., \& Kusuma Husada Surakarta, Stik. (2016). Pengaruh terapi musik gamelan untuk menurunkan skala nyeri pada lansia dengan osteoartritis di Panti Wredha Aisyiyah Surakarta. Jurnal Kesehatan Kusuma Husada. http://jurnal.ukh.ac.id/index.php/JK/article/view/156

Wurarah, M. L., Artur, P., Kawatu, T., Hasan, R., Fakultas, A., Universitas, K. M., Ratulangi, S., \& Belakang, A. L. (2020). Hubungan antara Beban Kerja dengan Kelelahan Kerja pada Petani. Indonesian Journal of Public Health and Community Medicine, 1(2), 006-010. https://doi.org/10.35801/IJPHCM.1.2.2020.28661 